\title{
July - December 2018
}
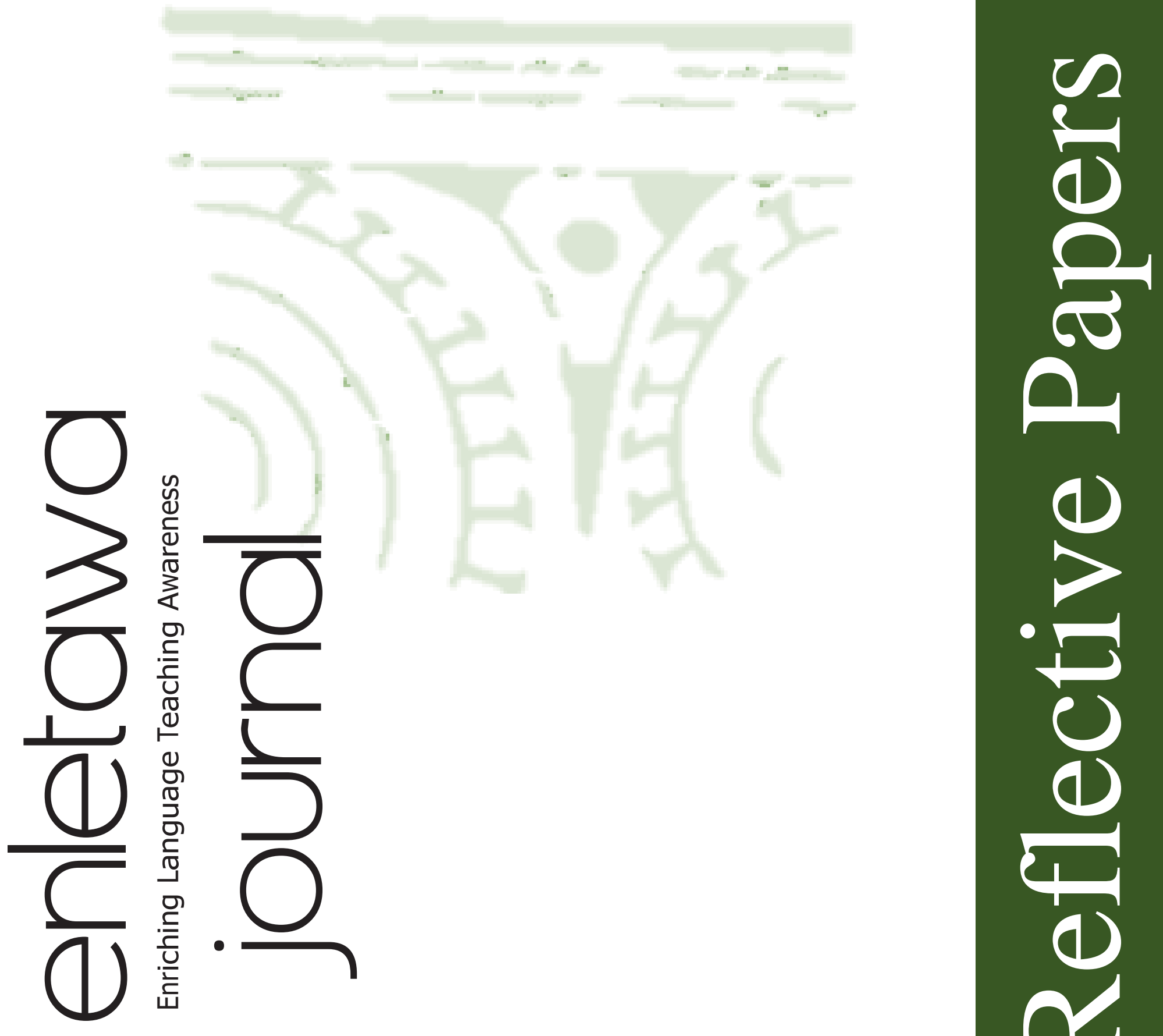

○

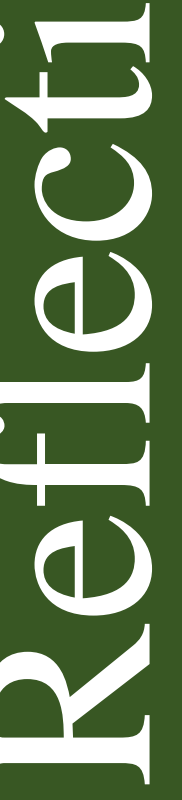

Vol. 11, No. 2 


\title{
EFL in Primary Classrooms of Choco: A Challenge for In-service Teachers and Educational Authorities ${ }^{1}$
}

\author{
Alexander Córdoba Mosquera ${ }^{2}$ \\ Universidad Tecnológica del Chocó "Diego Luis Córdoba" \\ d-alexander.cordobam@utch.edu.co
}

\section{Received: October 10, 2018}

Accepted: November 29, 2018

How to cite this article (APA, $\boldsymbol{6}^{\text {th }}$ ed.): Córdoba Mosquera, A. (2018). EFL in primary classrooms of Choco: A challenge for in-service teachers and educational authorities. Enletawa Journal, 11(2), 58-70.

\begin{abstract}
The following study explored choices and methods to improve professional training and development among primary school teachers from Chocó in order to enhance English teaching at the basic school level. The research work was an analyticaldescriptive study undertaken with in-service primary school teachers from ChocóColombia. The investigation analyzed the situation faced by primary school teachers from Chocó when teaching EFL (English as a Foreign Language) in the primary school classroom. Furthermore, the study, to some extent, describes the existence of social, cultural, political and academic factors which may intervene in the EFL context of Chocó's primary education as well.

Both quantitative and qualitative research methods were applied in the development of the investigation. A questionnaire was implemented as the quantitative data collection instrument and the interview as the qualitative one. Additionally, classroom observation was also used as an instrument to gather data.

The study has revealed that in-service primary teachers from Chocó lack the knowledge they need to teach English to young children as they are trained neither from a linguistic nor from a methodological point of view.
\end{abstract}

Key words: English, foreign language, primary classroom, in-service teachers, challenge, and authorities.

\footnotetext{
${ }^{1}$ Reflective Paper

${ }^{2}$ Alexander Córdoba Mosquera is a full-time professor at the Universidad Tecnológica del Chocó "Diego Luis Córdoba”. He holds a master's degree in English Didatics and a doctoral degree in Modern Languages, Literature, and Translation. His areas of expertise include education, foreign and modern language teaching, and translation.
} 


\section{Resumen}

Este estudio exploró opciones y posibilidades con el fin de incrementar el proceso de formación y desarrollo profesional de los docentes de educación primaria del Chocó para favorecer así la enseñanza del inglés a nivel de la educación básica. La investigación fue un estudio descriptivo-analítico desarrollado con los docentes activos en educación primaria en el Chocó.

Por lo tanto, la investigación ha analizado la situación que los docentes de primaria del Chocó afrontan a la hora de enseñar ILE (inglés como lengua extranjera) en el aula de educación básica. Igualmente, $y$, de manera general ha descrito la existencia de algunos factores sociales, culturales, políticos y académicos que, de una u otra forma, pueden intervenir en el proceso de enseñanza-aprendizaje del inglés como lengua extranjera en la educación primaria del Chocó.

Se aplicaron ambos métodos (cuantitativo y cualitativo). Es decir, se implementó un cuestionario como el instrumento de recogida de datos de tipo cuantitativo y la entrevista como el instrumento de tipo de cualitativo. Además, se utilizó la observación de aula para colectar la información.

El estudio ha revelado que el profesorado en servicio de primaria del Chocó carece de los conocimientos básicos para enseñar Inglés a los niños de dicho nivel; ya que no cuenta con formación ni lingüística ni metodológica para este fin.

Palabras claves: Inglés, lengua extranjera, aula de primaria, docentes en servicio, reto y autoridad. 


\section{Introduction}

According to Richards (2006, p. 1) the ever-growing need for sound communication skills in English has created a huge demand for English teaching worldwide. Today, millions of people want to improve their knowledge of English, or at least ensure that their children achieve a good domain of the language. In the past few decades, English has become a basic need to communicate in the modern and globalized world. Hence, acquiring this skill has become an urgent need for language teachers and learners alike in order to face the new era that we live in.

English, either as a native, second or foreign language, sets or determines the future for hundreds of professionals. Aware of such a salient phenomenon, the Colombian government has established that primary school teachers must teach English as a foreign language (EFL). Teaching foreign language demands preparation, but primary school teachers from Chocó are still in search of a solution to achieve such a goal.

\section{Research Questions}

1) Do primary school teachers have enough foreign language (FL) communicative competence in English?

2) Do primary school teachers have enough methodological knowledge to teach EFL?

3) Are in-service primary school teachers professionally prepared for teaching EFL in the primary classroom?

\section{General Research Objectives}

- To analyze the crucial situations that in-service primary school teachers from Chocó face in order to teach EFL in the primary classroom.

- Describe a varied-set of internal and external factors (social, cultural, political and academic), which may intervene in the integration of EFL in the primary school classroom in Chocó.

\section{Theoretical Framework}

During the last decades, English has become a basic necessity to communicate in the modern and globalized world. According to Syam (2012, p. 4), English is currently the most widely spoken language in the world. It is the mother-tongue of more than 320 million people, and another 200 million use it as their second language. Besides, English is an important foreign language almost anywhere in the world. In this respect, Kizildag (2009) affirmed that "English is the world language and serves as the lingua franca for business, education, political and technology contexts" (p. 1). Similarly, Rosner \& Bolitho (1990) stated that "these days English language teaching (...) is a local requirement in an era of worldwide information-sharing and commercial exchange" (p. 5).

The current reality related to teaching and learning English as a foreign language has persuaded many parents around the world that their children should start learning English at an early age, even if they live in a country where it may never be spoken. As Hill (cited in Rogers, 1990) argued, "in many countries parents insist on their children all learning a foreign language, because they believe that it will help them to get a good job" (p. 14). 
This is a mindset which is logically well founded on the ever-growing awareness people worldwide have about learning English as a foreign language. No father or mother wants his/her child to be deprived of that opportunity. As early as 1988, Prodromou stated that "the introduction of English into the primary school is imminent" (p. 37), and this is an ongoing reality today. Early introduction of EFL in the primary classroom has challenged primary school teachers to assume the responsibility of teaching the language, although some of them may not be linguistically or methodologically prepared for such a role.

Consequently, all over the world, most countries admit and acknowledge the need to become bilingual nations. Syam (2012) affirmed that English is, for example, the lingua franca in India, where many languages are spoken and diverse cultures and ethnic groups coexist. Cummins \& Davison (2007) coincided in stating that:

In countries like Nigeria, China, and India, the 'principal ingredient' of unification and strong unity is the English Language. India, a country of over a billion people, has many hundreds of local dialects and languages. In such a complicated situation, the State has given English the official language status to facilitate easy communication. (p. 5)

English fulfills a large number of utilitarian purposes, including the acquisition of all sorts of knowledge in a fast-moving world of information that we live in today (Syam 2012 p. 2). Similarly, Nair, Setia, Mohamad, Kadir, Luqman, Vadeveloo, and Ngah (2014) asserted that the English language is vital for an emerging economy like Malaysia's, where they have even included English literature in the EFL syllabus in schools for the past 11 years (p. 1). Though English has a restricted range of functions in Japan, it is taught extensively as a foreign language in the education system and is increasingly employed in international trade, overseas travel, and in academic research as well (McKenzie, 2010, p. 4). According to this author, the Minister of Japanese education has recognized the importance of English in the future of Japan and the world in general:

English has played a central role as the common international language in linking people who have different mother tongues. For children living in the 21 st century it is essential to acquire communication abilities in English as a common international language. In addition, English abilities are important in terms of linking our country with the rest of the world, obtaining the world's understanding and trust, enhancing our international presence and further developing our nation. (p. 9)

Thus, the English language is becoming more significant every day due to globalization and increased competition among nations. Therefore, there is an urgent necessity within developed and developing countries to train school teachers and educators in charge of teaching EFL in the classroom.

As stated above, the salient phenomenon of teaching English to young learners in the primary classroom is a very common situation shared by many of today's countries. For example, in nations like China and other developing countries, such as Turkey, Kenya and Indonesia, educational authorities have also promulgated national laws to include English in their curricula (China: 1995, Kenya: 1997, Indonesia: 2001). According to Madya, Sugeng, Maarif, Supriyanti, Purbani, and Istiqomah (2004), Kizildag (2009), Liu and Dai (2011), and Syomwene (2013), more than ten years have passed since the English language was introduced in the primary classroom of these countries. However, the statistical results 
concerning the target foreign language have not yet reached the desired level:

The advent of English in primary schools has an impact not only on college English, but also on every sector of the English teaching and learning community. The downward focus of the English education system also means the downward flow of English teachers. The problem of transferring and training English teachers for primary schools is not easy to be dissolved. The inadequacy of primary English teachers has been hindering the overall development of English education in China. It is hoped that with the shrinking job market for English major graduates, they will be encouraged, or forced, to work at primary schools. (Liu \& Dai, 2011 p. 3)

Colombia is not the exception in this mindset. The Common European Framework of References for Languages (Council of Europe, 2001) has been used to create the national standards for international comparison. The Department of National Education of Colombia has also implemented the National Program of Bilingualism 20042019, which includes the new standards of communicative competence in the foreign language. The main goal of the program is the improvement of the communicative competence in English throughout the entire educational system, as well as the cultivating national competitiveness. In other words, the Colombian government has understood that mastering English may set or determine the coming future for thousands of professionals in our country.

In Colombia, and especially in Chocó, EFL teachers face many difficulties in their daily practice when dealing with the foreign language in the primary classroom. In many cases, these challenges come from not knowing the nature of the language or how to teach it. In accordance to this statement, Denham \& Lobeck (2002) stated that EFL teachers must be aware of certain grammatical principles in order to help students recognize and learn grammatical patterns. Therefore, it is the teacher's job to provide their students with grammatical information. Unfortunately, this is something many teachers cannot do in Chocó as their level of English is too basic, and they scarcely have opportunities to improve their grammatical competence.

It is well known that the teacher training and updating process take time, strength, and sacrifice. Nevertheless, it is necessary to undertake such processes. Additionally, there must be a direct commitment from all of the actors involved in teachers' development and the ongoing training process. Educational authorities, teacher trainers, and trainee teachers themselves must be aware of the importance these processes have on children's educational and professional development. In other words, they should all pay attention to teachers' training and see it as a real chance for future teachers to improve their language and methodological skills. In this way, they can significantly guide children to real success in the target language. Met (1999) and, in a similar vein, Richardson (2005) also seemed to agree when stating that:

To start with the efficacy of language
teachers, they must be skillful enough to
monitor student performance and expert
in instructional designs; moreover, they
must be a model for the use of the target
language and teach language learning
strategies. All in all, they must form the
most appropriate atmosphere to make the
learning at its best. (cited in Kizildag,
2009, p. 2)

English teaching and learning-based research seems to be an undeniably important aspect in today's world because it intends to meet the needs of a wide variety of teachers and students involved in Chocó's primary education system. Consequently, teaching and 
research enable both teachers and students to better interact and survive, not only within the local, regional, or national context, but also within an international one as well.

In order to achieve the goal mentioned above in the Colombian society, teachers and educational institutions, both public and private, play a fundamental and decisive role. Among them, primary school teachers have a great role to play as they are in charge of teaching English to young learners in their classrooms, even though they do not have the language competence to do so. To face this challenge, they must be trained because, as this research will show, most primary school teachers in Colombia, and specifically in Chocó, are neither linguistically nor methodologically prepared to undertake such a mission.

The present investigation is therefore an analytical-descriptive study undertaken with in-service primary school teachers from all over the department of Chocó in Colombia. The main goal was focused on exploring, analyzing, and describing the situation these teachers face when teaching EFL in the primary classroom.

\section{Research Design and Methodology}

Research design and methodology might be understood as the key points of the practical dimension of an investigation. In other words, it can be understood as the logic or master plan of an investigation that sheds light on how the study is to be conducted. It shows how the most important elements of the research (samples or groups, measures, treatments or programs, etc.) work together in an attempt to address the research questions (Thomas, 2010, p.18). In the same respect, Mouton (1996) argued that "the research design serves to plan, structure and execute the research to maximize the validity of the findings. It gives directions from the underlying philosophical assumptions to research design and data collection" ( $\mathrm{p}$. 175). Similarly, the relevance of the research design is also supported by Yin (2003), who affirmed that "colloquially a research design is an action plan for getting from here to there, where 'here' may be defined as the initial set of questions to be answered and 'there' is some set of conclusions answers" (p. 19).

\section{Mixed Method Approaches}

The methodology of this ongoing research is based on the paradigm of the mixed method approach. Qualitative and Quantitative research methods were simultaneously applied in the research environments aimed at gathering a stronger, more suitable, and reliable sort of data. The data were interpreted and analyzed under the theoretical underpinnings of both research methods. In this juncture, Lakshman, Sinha, Biswas, and Charles (2000) have stated that "Quantitative and qualitative methods can be employed sequentially or simultaneously in a single study" (p. 4). They have become very useful in scientific research during the last few years, and as Zohrabi (2013) argued, "the mixed method approaches have recently risen to prominence. The reason that more researchers are opting for these types of research is that both, qualitative and quantitative data are simultaneously collected, analyzed and interpreted" (p.1).

The two research methods mentioned above were originally established in different fields of study, but even so, they can both be used in educational research. In this respect, Thomas (2010) remarked that "quantitative research methods were originally developed in the natural sciences to study natural phenomena. Qualitative research methods were 
developed in the social sciences to enable researchers to study social and cultural phenomena" (pp. 11-12). For this ongoing study, it is my belief that combining quantitative and qualitative methods will produce results with a higher level of trustworthiness and reliability. As Zohrabi (2013) commented, "it is believed that using different types of procedures for collecting data and obtaining that information through different sources (learners, teachers, program staff, etc.) can augment the validity and reliability of the data and their interpretation" ( $\mathrm{p}$. $1)$.

Even though an investigation can be carried out by implementing a single research method (quantitative or qualitative), the research results may be favored (in terms of trustworthiness and reliability) if a mixed-research methodology is used (Zohrabi, 2013). Thus, as stated before, the research method applied to undertake the present study was a mixed type. I applied quantitative and qualitative methodologies sequentially. First, I implemented a questionnaire, which was followed by an interview. Finally, I observed the classroom. These were the three main data collection instruments.

\section{Data Collection}

The department of Chocó has 30 municipalities (townships) and approximately six primary schools per municipality. For the practical development of this research study, the eight most outstanding municipalities, out of those 30 mentioned above, were selected. For each municipality, I selected one primary educational institution, two teachers, and one administrator per institution. This implied a total of 24 participants as the representative sample of the entire population. The following were the municipalities selected for the sample population: Quibdó, Istmina, Condoto, Tadó, Medio Sanjuan, Atrato, Certegui and Union Panamericana.

First, I applied the questionnaire to approximately 140 in-service primary school teachers in two educational institutions for each of the eight municipalities. From those 140 teachers, 24 were randomly post-selected by choosing one of the two institutions per municipality to undergo the interview. Therefore, I applied the interview to eight administrators (one per institution) and 16 in-service primary school teachers (two per each educational institution).

As a way to prove and validate the information collected from the two previous instruments, the last data collection technique was classroom observation. I applied this instrument to the same in-service primary school teachers I had previously interviewed. The main factors I observed were the teachers' English level, the methodology they used to teach the foreign language, their classroom management skills, and how they integrated ICTs in the EFL primary classroom. These factors were observed in detail through pre-designed observation sheets.

\section{Data Analysis}

\section{Analysis of the questionnaires and interviews applied to the primary school administrators and primary school teachers}

Questionnaires, addressed to administrators and primary school teachers, were statistically presented and analyzed in this section. The questions were originally asked in Spanish, but for publication purposes, I translated them to English. Additionally, I identified similar questions with the letters $\mathrm{A}$ and $\mathrm{B}$, while those that were addressed to a 
specific group of participants (different ones) were individually presented and identified with the letter C. In total, there were 16 primary school administrators and 125 primary school teachers who responded the questionnaire. Of the population that answered the questionnaire, I selected and interviewed 24 participants, which included eight administrators and 16 primary school teachers. Moreover, I decided to analyze both instruments together as the questions were the same, although some of the questions in the questionnaire were not included in the interview. A sample of the questions are presented below as an illustration.

\section{Question 1}

A. Is your institution required to teach English to children?

B. Are you, as a primary school teacher, required to teach English in Primary Education? Please, justify your answer.

Table 1

Analysis of the Questionnaire and Interview for Question 1.

\begin{tabular}{||ccc||}
\hline & \multicolumn{2}{c|}{ ADMINISTRATORS } \\
\cline { 2 - 3 } ANSWER & $\frac{\text { NUMBER }}{16}$ & $\frac{\text { PERCENTAGE }}{10}$ \\
YES & 0 & $100 \%$ \\
NO & 16 & $0 \%$ \\
TOTAL & TEACHERS & $100 \%$ \\
& $\frac{\text { NUMBER }}{114}$ & PERCENTAGE \\
ANSWER & 10 & $91 \%$ \\
YES & 1 & $8 \%$ \\
NO & & $1 \%$ \\
NO & 125 & $100 \%$ \\
ANSWER & & \\
TOTAL & & \\
\hline
\end{tabular}

In the example above, I asked the administrators Question A, while the primary school teachers answered Question B. As we can see in Table 1, $100 \%$ of the administrators and most of the teachers (91\%) agreed that it was mandatory for them to teach English as a foreign language in primary school. They also stated that including English as a foreign language in their curricula was imposed by the state.
During the interview, one of the administrators added that there was no real support from the national government:

Así es como lo establece la ley, pero además de que se trata de un idioma muy importante para los niños jamás hemos visto algún tipo de ayuda de parte del estado para dicho proceso, solo lo exigen y nada más.

[That is how the law establishes it. Despite being an important language for the children, we have never seen any type of help from the state for these process. They only demand and nothing else.]

Primary teachers shared the same opinion:

Este proceso ha sido establecido en la ley general de educación (115). Además, porque estamos hablando de un idioma muy importante para el fututo de los niños; sin embargo, no existe apoyo para dicho proceso.

[This process has been established in the general law of education (115). Additionally, we are talking about a language that is really important for the future of our children. Nonetheless, no support is given for this process.]

\section{Question 2}

A. Does your institution receive any kind of support for that purpose? If the answer is affirmative, what kind of support?

B. Does the Administration support the teaching of English? If the answer is yes, are you satisfied with that support?

Table 2

Analysis of the Questionnaire and Interview for Question 2.

\begin{tabular}{|c|c|c|}
\hline \multicolumn{3}{|c|}{ ADMINISTRATORS } \\
\hline ANSWER & NUMBER & PERCENTAGE \\
\hline YES & 6 & $\mathbf{3 7} \%$ \\
\hline No & 10 & $63 \%$ \\
\hline TOTAL & 16 & $100 \%$ \\
\hline \multicolumn{3}{|c|}{ TEACHERS } \\
\hline ANSWER & NUMBER & PERCENTAGE \\
\hline YES & 31 & $\mathbf{2 5} \%$ \\
\hline No & 69 & $\mathbf{5 5} \%$ \\
\hline No & 25 & $20 \%$ \\
\hline \multicolumn{3}{|l|}{ ANSWER } \\
\hline TOTAL & 125 & $100 \%$ \\
\hline
\end{tabular}


Table 3

Analysis of the classroom observation format.

\begin{tabular}{|c|c|}
\hline Teacher's Aspects to be Observed & The Observation Findings \\
\hline $\begin{array}{l}\text { Does the teacher speak English all the } \\
\text { time? }\end{array}$ & $\begin{array}{l}\text { None of the teachers spoke English during the } \\
\text { sessions. They uttered only a few isolated words. } \\
\text { Observation corroborated that their knowledge of the } \\
\text { foreign language was very limited. }\end{array}$ \\
\hline Does she/he make many mistakes? & $\begin{array}{l}\text { The few words uttered or written by the teachers } \\
\text { contained different pronunciation or spelling } \\
\text { mistakes. When they had to read a short text, they } \\
\text { also had a lot of mistakes. }\end{array}$ \\
\hline $\begin{array}{l}\text { What kind of methodology does the } \\
\text { teacher use? }\end{array}$ & $\begin{array}{l}\text { Most teachers used very traditional methodologies, } \\
\text { especially Grammar Translation. }\end{array}$ \\
\hline $\begin{array}{l}\text { Are the students provided with speaking } \\
\text { activities? What type? Are they } \\
\text { motivating? }\end{array}$ & $\begin{array}{l}\text { None of the teachers provided speaking activities. } \\
\text { They mainly utilized translation and very controlled } \\
\text { written activities }\end{array}$ \\
\hline $\begin{array}{l}\text { How are reading skills practiced? What } \\
\text { types of reading activities are used? Are } \\
\text { they motivating? }\end{array}$ & Reading was not promoted during the sessions. \\
\hline $\begin{array}{l}\text { How are listening activities completed? } \\
\text { What kind of listening activities are used? } \\
\text { Are they motivating? }\end{array}$ & $\begin{array}{l}\text { Listening activities were not fostered during the } \\
\text { sessions observed. }\end{array}$ \\
\hline $\begin{array}{l}\text { How are writing activities completed? } \\
\text { What types of written activities are used? } \\
\text { Are they motivating? }\end{array}$ & $\begin{array}{l}\text { Writing was not promoted either. Students were } \\
\text { limited to writing a few misspelled words on the } \\
\text { whiteboard. }\end{array}$ \\
\hline $\begin{array}{l}\text { Is there a balance among activities? Does } \\
\text { the teacher integrate the different skills? }\end{array}$ & $\begin{array}{l}\text { The four basic skills were not practiced effectively } \\
\text { during the observed sessions and it can also be said } \\
\text { that the balance between activities was nearly non- } \\
\text { existent. }\end{array}$ \\
\hline $\begin{array}{l}\text { What is the role of grammar } \\
\text { teaching/learning in the classroom? }\end{array}$ & $\begin{array}{l}\text { Most teachers did not teach grammar during the } \\
\text { lessons. Teachers limited themselves to writing } \\
\text { isolated words on the whiteboard, but no grammar } \\
\text { rules were practiced. }\end{array}$ \\
\hline $\begin{array}{l}\text { What kind of strategies does he/she use to } \\
\text { make himself/herself understood? }\end{array}$ & Teachers used mostly Spanish for clarification. \\
\hline
\end{tabular}


It should be noted that $37 \%$ of the administration staff argued that the national government supports them by offering some basic workshops and/or lectures to prepare teachers to teach the foreign language. Nonetheless, 63\% agreed that there is no support coming from the government with that objective in mind. Concerning primary teachers, $55 \%$ of them said that there is no real support in that sense. It seems that the government and national educational authorities do not offer enough support so that the demanded goal could be met.

\section{Observation carried out within the EFL Primary Classroom}

The observational process conducted within the EFL primary classroom is presented and analyzed in this section. This process of observation was aimed at 1) detecting the foreign language level of the primary teachers, 2) their teaching knowledge and skills, and 3) how they managed to integrate ICT devices and tools in the primary school classroom. A template of the observation sheets is provided below.

\section{Observation Task 2 -Teacher's Knowledge in EFL/TEFL}

According to observations carried out, it seems clear that most teachers were not trained professionally to speak the English language or to teach it. Consequently, they were not able to provide adequate teaching practice to the young children they worked with. I also perceived during the observations that most of them were only able to manage a basic repertoire of words that they tended to mispronounce or misspell when uttered or written on the whiteboard.

\section{Concerning classroom} methodology, I noticed that a concrete methodological orientation for teaching English was not apparent. Rather, most teachers showed an orientation to use traditional methods, such as the Grammar Translation for instance. Furthermore, during the process of classroom observation, concrete activities which enhanced the four basic English skills developments with the children could not be seen.

\section{Discussion of the Results}

After analyzing the information obtained from the instruments, the findings were purposely grouped into three main categories that emerged from the initial hypothesis and research questions. Additionally, the participants' voices and testimonies have been taken into account in order to establish the following categories:

- Lack of state support to include TEFL in Primary Education

The investigation has corroborated that the Colombian government has made it mandatory for basic primary institutions to include TEFL in their curricula as a compulsory subject. It has been equally shown that national educational authorities do not offer enough support to successfully meet goals in terms of teaching English in the primary school classroom. In other words, real support for these goals are nearly nonexistent in the primary school institutions of Chocó; the demand exists, but significant support to achieve these demands is not provided.

Este proceso ha sido establecido en la ley general de educación (115). Además, porque estamos hablando de un idioma mиy importante para el fututo de los niños; sin embargo, no existe apoyo para dicho proceso.

[This process has been established in the general law of education (115). Additionally, we are talking about a language that is really important for the future of our children. Nonetheless, no support is given for this process.] 
Additionally, one of the administrators added that,

En realidad nos hace falta capacitación en este sentido, no contamos ni con un nivel básico en el idioma inglés.

[In reality, we need more training in this sense. We do not count on a basic level of the English language.]

- English level of in-service primary school teachers

The study has also shown that primary teachers' linguistic and methodological knowledge of English is extremely poor or low. This fact prevents them from teaching children the target language successfully. In a similar vein, the observational process has reaffirmed that the in-service primary teachers of Chocó were not trained professionally to speak the English language. They do not have a high enough level to teach any of the four main skills. Concerning this, participants have coincided in stating that:

porque a ellos no se les impartió dicho conocimiento durante sus periodos de formación profesional, ni tampoco se les ha formado para ello ahora que ya están en servicio.

[because this knowledge was not given to them during their period of professional training. Also, they have not received this type of training now that they are in service.]

- Pre-service and in-service teachers' training in TEFL

Most primary school teachers hold the title of Licenciados en Educación Básica Primaria [Bachelor's in Primary Basic Education] with an emphasis on any of the compulsory areas they need to work with, such as mathematics, Spanish language or sciences. Nonetheless, English or English Foreign Language Teaching (EFLT) methodology is usually not emphasized. Furthermore, in-service teaching programs are not considered by educational authorities to improve teachers' lack of linguistic and methodological knowledge. Thus, and according to what was found during this investigation, in-service primary school teachers from Chocó have scarce preparation in English, which does not allow them to teach this language confidently to young children. They are trained neither in the linguistic component of the language nor in its methodological component. This fact does not allow them to teach the target language significantly and effectively according to them.

\section{The Research Conclusions}

All in all, according to the results obtained, primary teachers from Chocó lack the knowledge they need to teach English to young children in a confident manner since they are trained neither from a linguistic nor a methodological point of view.

Although the Ministry of Education in Colombia established several laws and decrees to spread the knowledge of English in primary education throughout the country, it seems that they have overlooked one of the most important pieces of that educational improvement: the training of in-service primary teachers in charge of implementing innovation. According to the government, most of the Colombian population should speak English by the year 2019. According to the national reality, this seems to be a difficult objective to achieve.

It is obvious that primary education sets the basis for a child's further intellectual development, and that learning a foreign language (especially English) has become paramount in our society. It is clear then that children are the subjects most affected by this educational negligence, as they cannot receive quality instruction from professionals who have been prepared to do so. 
Numerous

pedagogical

implications may be drawn from this research study related to the processes of language teacher development and training. The present investigation has been primarily focused on the Chocoanean educational context in Colombia, specifically on those inservice teachers who work at the primary school level. As a main objective, the study sought to contribute to the improvement of the quality of language teaching and learning education in general.

In other words, this study began, first of all, to clarify the existence of serious problems in terms of a lack of suitable training for both teachers and pupils. Secondly, the study aimed to provide a number of suggestions and/or recommendations to the national educational authorities and primary school teaching staff (administrators and teachers), especially those who have participated directly in the development of the research and are part of the situation.

Perhaps, due to the particular contextualization of this investigation, its results should not be overgeneralized. However, I firmly expect that the following suggestions and/or recommendations may be significant to the field of foreign language teaching and learning pedagogy, not only in Chocó, but in other regions of the country that may be dealing with the same processes, experiences, and problems.

\section{References}

Council, O. E. (2001). Common

European Framework of

Reference for Languages:

Learning, Teaching. Assessment.

Cummins, J., \& Davison, C. (Eds.). (2007). International handbook of English language teaching. New York: Springer Science \& Business Media.

Denham, K., \& Lobeck, A. (2002). A practical grammar course: A (partially) annotated syllabus in syntax in the schools. The Journal of the Assembly for the Teaching of English Grammar, 18 (2), 1-6.

Kizildag, A. (2009). Teaching English in Turkey: Dialogues with teachers about the challenges in public primary schools. International Electronic Journal of Elementary Education, 1 (3), 188-201.

Lakshman, M., Sinha, L., Biswas, M., Charles, M., \& Arora, N. K. (2000). Quantitative vs qualitative research methods. The Indian Journal of Pediatrics, 67 (5), 369-377.

Liu, J., \& Dai, Z. (2011). The impact of the advent of English in primary schools on the development of college English in China. Higher Education Studies, 1 (1), 105108.

Madya, S., Sugeng, B., Maarif, S., Supriyanti, N., Purbani, W., \& Istiqomah, S. (2004). Developing a model of teaching English to primary school students. Teflin, 15 (2), 193-229. 
McKenzie, R. M. (2010). The global spread of English and the role of English in Japan. In McKenzie, R. M. (Ed.), The social psychology of English as a global language. pp. 1-18. Dordrecht: Springer.

Met, M. (1999). Content-based instruction: Defining terms, making decisions. Retrieved from

http://carla.umn.edu/cobaltt/mod ules/principles/decisions.html

Mouton, J. (1996). Understanding Social Research. Pretoria: Van Schaik Publishers.

Nair, G. K. S., Setia, R., Mohamad, R., Kadir, Z. B. A., Luqman, A., Vadeveloo, T., \& Ngah, H. C. (2014). Attitude, parental encouragement and perception of the importance of English in English language learning. Asian Social Science, 10 (3), 1-8.

Retrieved from:

http://ezproxy.msvu.ca/login?url $=\mathrm{http}: / /$ search.proquest.com/doc view/1503675476?accou ntid $=1261$.

Prodromou, L. (1988). English as cultural action. In Rossner, R., \& Bolitho, R. (Eds.) (1990), Currents of change in English language teaching. pp. 28-46. Oxford: Oxford University Press.

Rogers, J. (1990). The world for sick proper. In Rossner, R., \& Bolitho, R. (Eds.). Currents of change in English language teaching. pp. 8-17 Oxford: Oxford University Press.

Rossner, R., \& Bolitho, R. (Eds.). (1990). Currents of change in English language teaching. Oxford: Oxford University Press. Sage Publications Inc.
Syam, N. (2012). Importance of English in India. Language in India, 12 (9), 455.

Syomwene, A. (2013). The Teaching of oral communication skills in the English curriculum in primary schools in Kenya. European Scientific Journal, 9 (28), 56-65.

Thomas, P.Y. (2010). Towards developing a web-based blended learning environment at the University of Botswana. (Doctoral Thesis) University of South Africa. Retrieved from: http://uir.unisa.ac.za/handle/105 $00 / 4245$ ? show $=$ full

Yin, R. K. (2003). Case study research: Design and methods. Thousand Oaks, California: Sage Publications.

Zohrabi, M. (2013). Mixed method research: Instruments, validity, reliability and reporting findings. Theory and Practice in Language Studies, 3 (2), 254262. Retrieved from http://search.proquest.com/docvi ew/1330861295? accountid=144 75 